\title{
Lysocardiolipin Acyltransferase 1
}

National Cancer Institute

\section{Source}

National Cancer Institute. Lysocardiolipin Acyltransferase 1. NCI Thesaurus. Code C102935.

Lysocardiolipin acyltransferase 1 (414 aa, $49 \mathrm{kDa}$ ) is encoded by the human LCLAT1 gene. This protein plays a role in lipid acylation. 